\title{
El Procesamiento y la Calidad de Alimentos
}

\author{
Food Processing and Quality
}

\section{Ah-Hen, K. ${ }^{a}$, Muñoz, O. ${ }^{a}$, Puente, L. ${ }^{b}$, Parada, J. ${ }^{a}$, Vega-Gálvez, A. ${ }^{c}$, Carrillo, B. ${ }^{a}$, Lemus-Mondaca, R. ${ }^{b}$, Bastías-Montes, J.M. ${ }^{d}$, Velez-Pacio D. ${ }^{e}$, Corpas, E $f$, DiScala, K. ${ }^{g, h}$, Devesa y Pérez, V. ${ }^{e}$}

\author{
${ }^{a}$ Instituto de Ciencia y Tecnología de loa Alimentos, Facultad de Ciencias Agrarias, \\ Universidad Austral de Chile, Valdivia, Chile. \\ ${ }^{b}$ Departamento Ciencia de los Alimentos y Tecnología Química, Facultad de Ciencias Químicas y Farmacéuticas, \\ Universidad de Chile, Santiago, Chile. \\ c Departamento de Ingeniería en Alimentos, Facultad de Ingeniería, Universidad de La Serena, La Serena, Chile. \\ ${ }^{d}$ Departamento de Ingeniería en Alimentos, Universidad del Bío-Bío, Chillán, Chile. \\ ${ }^{e}$ Instituto de Agroquímica y Tecnología de los Alimentos, CSIC, España. \\ ${ }^{f}$ Universidad Católica de Manizales, Manizales, Caldas, Colombia. \\ ${ }^{g}$ Facultad de Ingeniería, Universidad Nacional Mar del Plata, Mar del Plata, Argentina \\ ${ }^{h}$ Consejo Nacional de Investigaciones Científicas y Técnicas (CONICET), Argentina.
}

\section{E D I T O R I A L}

Food processing cannot be perceived without considering the quality of the desired products. This involves the transformation of the raw material into food products of different categories (semi-finished or ready-to-eat products) using various techniques, from the simplest to the most sophisticated. The simplest techniques, such as sun-drying or direct heating have been used since ancient times with the primary goal to achieve long shelf-life or a tasty food with the quality characteristics of being innocuous and nutritious. Modern technology has maintained the same goals; however, the level of complexity and requirement have changed owing to a better understanding of processing methods. The development of technologies directly or indirectly related to food production has also led to quality improvement. Since the first experiment of Nicolás Appert in 1809 to sterilise food in a glass container, and the first tin container developed by Peter Durand in 1810 , the canning industry has undergone an extraordinary transformation, from improvement of packaging materials to the introduction of high technology in process control, making use of information technology, as well as in the organisation of food production to process the raw material. Furthermore, emerging technologies are being integrated more and more to respond to another technological challenge, focused on improving the quality of processed foods. The history of food processing is still being written to this day and the need to disclose knowledge in this area is highly relevant. Research in food science, food engineering and food technology has allowed a better understanding of production processes, making it possible to surmount obstacles that constantly arise in the arduous task of ensuring food safety along with high production efficiency.

In the era of globalisation, the food sector has a major role to play in commercial exchange activities, where business complexity requires detailed information on the products, their components, their quality attributes, as well as on the processing methods and traceability. Undoubtedly, such information can be obtained from the results of scientific research and through published articles. Chile, a country integrated within the international community and having the proposed intention to become a leader in food production, needs every effort of the entire population in all areas of activities to achieve this goal. Consequently, academy should get involved and has a contribution to make. In the southern part of the country, the scientific research carried out in the agri-food sector has had Universidad Austral de Chile (UACh) as the leading research institution, whereby the Agro Sur Journal would be created back in 1973 at the Faculty of Agricultural Sciences as a tool to promote scientific publications and to provide visibility of the research work being conducted. Since then Agro Sur Journal has been an indispensable means to disclose the achieved advances in agricultural sciences, which include soil science, plant and animal science, and even the social field with rural development and agrarian economy. Scientific contributions in this field are wide-open and extensive, and the Faculty of Agricultural Sciences at UACh, keen to support the agri-food chain, from field to fork, has also promoted the area of food science and food engineering that in turn contributes with studies on food processing to add value to the agricultural products. Therefore, with Agro Sur Journal the aims were set to give support and to contribute to the development of the country from the south. The compilation and publication of scientific research are firm proposals of Agro Sur Journal. This year the special edition of Agro Sur is dedicated to "Food Processing and Quality" to emphasise its compromise with food scientists and to participate in the publication of the book of abstracts of the XXI Conference of the Chilean Society of Food Technology (SOCHITAL), under the theme "Food Engineering for Nutrition and Health: An Integrative Approach to Design of Healthy Foods", held in Santiago from 22-24 May 2017 and organised by the School of Nutrition and Dietetics of Universidad de los Andes. 


\section{EDITORIAL}

El procesamiento de alimentos es inconcebible sin la consideración de la calidad de los productos que se quiere obtener. Esto involucra la transformación de la materia prima en productos alimenticios de distintas categorías (productos semi-elaborados o productos listos para el consumo), usando diversas técnicas, desde las más simples hasta las más sofisticadas. Las técnicas más simples, tales como el secado al sol o la cocción a fuego directo han sido usadas desde tiempos remotos con el objetivo primordial de lograr un alimento de larga vida o de agradable sabor y con características de calidad inocua y nutritiva. La tecnología moderna sigue con las mismas metas, aunque el nivel de sofisticación como también de exigencia han cambiado gracias a una mejor comprensión de los procesos. El desarrollo de las tecnologías de uso directo o indirecto en la producción de alimentos ha permitido mejorar su calidad. Desde la presentación del primer producto alimenticio esterilizado en su envase de vidrio por Nicolás Appert en 1809 y el primer envase de hojalata desarrollado por Peter Durand en 1810, la industria conservera ha experimentado un desarrollo vertiginoso. Esto ha pasado desde el mejoramiento de los materiales de envase hasta la utilización de alta tecnología, tanto en los métodos de control de procesos, haciendo uso de la tecnología de información, como también en el manejo de los mismos procesos productivos para la transformación y tratamiento de la materia prima. Además, se están integrando cada vez más las tecnologías emergentes, que responden a otro desarrollo tecnológico enfocado en mejorar la calidad de los alimentos procesados. La historia del procesamiento de los alimentos se sigue escribiendo hasta hoy en día y la necesidad de divulgación en este ámbito es muy relevante. El desarrollo de la ciencia, ingeniería y tecnología de alimentos ha permitido la comprensión de los procesos de producción para superar los obstáculos que constantemente surgen en la ardua tarea de asegurar la inocuidad de los alimentos junto con lograr alta eficiencia en la producción.

En la era de la globalización, el rubro alimenticio tiene un rol preponderante en el intercambio comercial que, siendo muy complejo, requiere de información, de los mismos productos, sus componentes, sus atributos de calidad, de la forma del procesamiento y su trazabilidad. Lo anterior, sin duda se obtiene a través de la investigación científica y la divulgación en artículos escritos. En ese contexto, Chile, país integrado en la comunidad internacional y que mantiene en su horizonte de desarrollo convertirse en una potencia alimentaria, sin duda requiere el esfuerzo de toda su población en todos los ámbitos para lograr esta meta. Ahí, la academia tiene su participación y un aporte que hacer. En el sur del país, se realiza investigación científica en el área agroalimentaria, la que ha sido liderada por la Universidad Austral de Chile (UACh). Por ello, y como una herramienta de divulgación científica de la investigación desarrollada en esta casa de estudios, se creó en el año 1973 la revista Agro Sur bajo el alero de la Facultad de Ciencias Agrarias. Desde entonces Agro Sur ha sido un medio imprescindible para la divulgación de los avances logrados en las ciencias agrarias, incluyendo la ciencia del suelo, la ciencia vegetal y animal, abarcando inclusive el ámbito social con el desarrollo rural y la economía agraria. El aporte es amplio y creciente y la Facultad de Ciencias Agrarias de la UACh apostando por la cadena agroalimentaria, desde el suelo a la mesa, ha fomentado también la ciencia e ingeniería en alimentos, la cual hace su contribución con los procesos para agregar valor a los productos del agro. Por lo tanto, con la revista Agro Sur se quiere apoyar y aportar al desarrollo del país desde el Sur. La recopilación y la divulgación de resultados de investigaciones científicas es una propuesta firme de la revista Agro Sur. Este año la edición especial de Agro Sur se dedica al "Procesamiento y Calidad de los Alimentos" para recalcar su adhesión a los investigadores del rubro alimentos, sumando su participación con la publicación del libro de resúmenes del XXI Congreso Chileno de Ciencias y Tecnología de Alimentos SOCHITAL 2017, bajo el lema "Ingeniería de Alimentos para Nutrición y Salud: un Enfoque Integrado para el Diseño de Alimentos Saludables" celebrado en Santiago el 22-24 de mayo 2017 y organizado por la Escuela de Nutrición y Dietética de la Universidad de los Andes. 